\title{
Photodegradation Of Basic Fuchsin Dye Using Titanium Dioxide Doped With Nitro- gen Photocatalysts
}

\author{
Lydia. $C^{1}$ and Allen Gnana Raj. $G^{2}$ \\ ${ }^{1,2}$ Department of Chemistry and Research Centre, Scott Christian College (Autonomous), \\ Nagercoil. Affiliated to Manonmaniam Sundaranar University, \\ Abishekapatti, Tirunelveli, Tamil Nadu, India.
}

\begin{abstract}
Photodegradation process of Basic Fuchsin dye by practical application of doped titanium dioxide nanoparticle based on green chemistry aspects of design for degradation efficiency. Titanium dioxide photo-catalysts with nitrogen as dopants were synthesized using different quantities using drying and heating methods and the degradation process using artificial light and the former was characterized using EDAX, Ultraviolet Spectroscopy, Infrared Spectroscopy, Scanning electron microscope. $\mathrm{pH}$ changes were determined. The photocatalytic activity was analyzed by photo degradation of Basic Fuchsin dye with different parameters under photocatalytic irradiation. The experiment results in an increment of degradation of the dye by the photocatalytic activity.
\end{abstract}

Keywords: Photo degradation, Dye, Titanium dioxide, Basic Fuchsin.

\section{Introduction}

Dyes are colourful compounds that can impart colour to anything that interacts with it; however, the harmful effects subsist in most of the human activities and new inventions. The effluents of the dye have been identified as harmful because of its toxicity and its nature of non-biodegradation which is considered as a source of pollution in water resource and in soil burial activities [1].

Basic Fuchsin dye has been used in textile industries [2] and degradation of this dye using nitrogen doped titanium dioxide has been studied in this paper.

\section{Review of Literature}

Tahshina Begum et al., issued a publication on "photocatalytic degradation on crystal violet dye on the surface of $\mathrm{Au}$ doped $\mathrm{TiO}_{2}$ nanoparticle", which covers preparation of gold doped titanium dioxide nanoparticle using $\mathrm{HAuCl}_{4}$, which shows increased efficiency of crystal violet dye degradation [3].

\section{Materials and Method}

Basic Fuchsin dye (Sigma Aldrich), Titanium dioxide (Spectrum Chemical), Urea (Spectrum Chemical), Double distilled water, Acetone, Hydrochloric acid was used for cleaning purposes, Steam bath, Muffle furnace, $\mathrm{KBr}$ pellets for IR spectroscopy.

\section{Experimental Procedure}

The synthesis of nitrogen doped titanium dioxide requires the proportions of titanium dioxide and urea at the ratios of $1: 1,1: 2[4]$. The mixture was dissolved with double distilled water and stirred in the magnetic stirrer and evaporated using steam bath and the product was scrapped off from the container. The samples were kept in the muffle furnace for 4 hours at $400,500,600^{\circ} \mathrm{C}$. The Basic Fuchsin dye was dissolved in the double distilled water and the absorbance was checked and an initial value $\left(\mathrm{I}_{0}\right)$ of wavelength $537.2 \mathrm{~nm}$. The Dye were tested for various parameters like dye solution in the dark, light alone, dark with the catalysts and light with the photocatalysts and the absorbance was taken at a time interval of 30 minutes to find intensity of light in the samples [5].

\section{Results and Discussion}

\section{Determination of $\mathrm{pH}$}

Before the degradation of the dye was 6.5

After implying photocatalyst was 7- 8.6 


\section{Tables and Figures}

Table:1 Dye in the dark

\begin{tabular}{|c|c|c|}
\hline $\begin{array}{c}\text { Time } \\
\text { (hours) }\end{array}$ & Wavelength(nm) & Absorbance(a.u) \\
\hline 0 & $537.2\left(\mathrm{I}_{0}\right)$ & 0.953 \\
\hline 0.5 & & 0.952 \\
\hline 1 & & 0.952 \\
\hline 1.5 & & 0.953 \\
\hline 2 & & 0.953 \\
\hline 2.5 & & 0.953 \\
\hline 3 & & 0.953 \\
\hline
\end{tabular}

Table:2 Dye in dark with $0.01 \mathrm{~g}, 1: 1,400^{\circ} \mathrm{C} \mathrm{pc}$ (photocatalyst)

\begin{tabular}{|c|c|c|}
\hline time & wavelength & absorbance \\
\hline 0 & 537.2 & 0.953 \\
\hline 0.5 & & 0.949 \\
\hline 1 & & 0.935 \\
\hline 1.5 & & 0.924 \\
\hline 2 & & 0.904 \\
\hline 2.5 & & 0.888 \\
\hline 3 & & 0.885 \\
\hline
\end{tabular}

Table:3 Dye in the dark with $0.01 \mathrm{~g}, 1: 1,500^{\circ} \mathrm{C} \mathrm{pc}$

\begin{tabular}{|c|c|c|}
\hline time & wavelength & absorbance \\
\hline 0 & 537.2 & 0.953 \\
\hline 0.5 & & 0.95 \\
\hline 1 & & 0.943 \\
\hline 1.5 & & 0.937 \\
\hline 2 & & 0.92 \\
\hline 2.5 & & 0.89 \\
\hline 3 & & 0.876 \\
\hline
\end{tabular}

Table:4 Dye in the dark with $0.01 \mathrm{~g}, 1: 1,600^{\circ} \mathrm{C} \mathrm{pc}$

\begin{tabular}{|c|c|c|}
\hline time & wavelength & absorbance \\
\hline 0 & 537.2 & 0.953 \\
\hline 0.5 & & 0.941 \\
\hline 1 & & 0.938 \\
\hline 1.5 & & 0.925 \\
\hline 2 & & 0.928 \\
\hline 2.5 & & 0.9 \\
\hline 3 & & 0.886 \\
\hline
\end{tabular}

Table:5 Dye in the light alone

\begin{tabular}{|c|c|c|}
\hline time & wavelength & absorbance \\
\hline 0 & 537.2 & 0.953 \\
\hline 0.5 & & 0.951 \\
\hline 1 & & 0.9 \\
\hline 1.5 & & 0.989 \\
\hline 2 & & 0.978 \\
\hline 2.5 & & 0.874 \\
\hline 3 & & 0.8 \\
\hline
\end{tabular}

Table:6 Dye in light with $0.01 \mathrm{~g}, 1: 1,400^{0} \mathrm{Cpc}$

\begin{tabular}{|c|c|c|}
\hline time & wavelength & absorbance \\
\hline 0 & 537.2 & 0.953 \\
\hline 0.5 & & 0.925 \\
\hline 1 & & 0.864 \\
\hline 1.5 & & 0.733 \\
\hline 2 & & 0.678 \\
\hline 2.5 & & 0.627 \\
\hline 3 & & 0.432 \\
\hline
\end{tabular}

Table:7 Dye in light with $0.01 \mathrm{~g}, 1: 2,400^{\circ} \mathrm{Cpc}$

\begin{tabular}{|c|c|c|}
\hline time & wavelength & absorbance \\
\hline 0 & 537.2 & 0.953 \\
\hline 0.5 & & 0.836 \\
\hline 1 & & 0.728 \\
\hline 1.5 & & 0.682 \\
\hline 2 & & 0.628 \\
\hline 2.5 & & 0.593 \\
\hline 3 & & 0.472 \\
\hline
\end{tabular}

Table: 8 Dye in light with $0.01 \mathrm{~g}, 1: 1,500^{\circ} \mathrm{Cpc}$

\begin{tabular}{|c|c|c|}
\hline time & wavelength & absorbance \\
\hline 0 & 537.2 & 0.953 \\
\hline 0.5 & & 0.836 \\
\hline 1 & & 0.752 \\
\hline 1.5 & & 0.74 \\
\hline 2 & & 0.67 \\
\hline 2.5 & & 0.627 \\
\hline 3 & & 0.513 \\
\hline
\end{tabular}


ISSN 2455-6378

Table:9 Dye in light with $0.01 \mathrm{~g}, 1: 2,500^{\circ} \mathrm{Cpc}$

\begin{tabular}{|c|c|c|}
\hline time & wavelength & absorbance \\
\hline 0 & 537.2 & 0.953 \\
\hline 0.5 & & 0.81 \\
\hline 1 & & 0.808 \\
\hline 1.5 & & 0.753 \\
\hline 2 & & 0.695 \\
\hline 2.5 & & 0.658 \\
\hline 3 & & 0.624 \\
\hline
\end{tabular}

Table:10 Dye in light with $0.01 \mathrm{~g}, 1: 1,600^{\circ} \mathrm{Cpc}$

\begin{tabular}{|c|c|c|}
\hline Time & wavelength & absorbance \\
\hline 0 & 537.2 & 0.953 \\
\hline 0.5 & & 0.885 \\
\hline 1 & & 0.873 \\
\hline 1.5 & & 0.803 \\
\hline 2 & & 0.709 \\
\hline 2.5 & & 0.671 \\
\hline 3 & & 0.58 \\
\hline
\end{tabular}

Table:11 Dye in light with $0.01 \mathrm{~g}, 1: 2,600^{\circ} \mathrm{C} \mathrm{pc}$

\begin{tabular}{|c|c|c|}
\hline time & wavelength & absorbance \\
\hline 0 & 537.2 & 0.953 \\
\hline 0.5 & & 0.904 \\
\hline 1 & & 0.886 \\
\hline 1.5 & & 0.836 \\
\hline 2 & & 0.73 \\
\hline 2.5 & & 0.717 \\
\hline 3 & & 0.692 \\
\hline
\end{tabular}

Table: 12 Dye in light with $0.02 \mathrm{~g}, 1: 1,400^{\circ} \mathrm{Cpc}$

\begin{tabular}{|c|c|c|}
\hline time & wavelength & absorbance \\
\hline 0 & 537.2 & 0.953 \\
\hline 0.5 & & 0.934 \\
\hline 1 & & 0.898 \\
\hline 1.5 & & 0.87 \\
\hline 2 & & 0.849 \\
\hline 2.5 & & 0.833 \\
\hline 3 & & 0.741 \\
\hline
\end{tabular}

Table:13 Dye in light with $0.02 \mathrm{~g}, 1: 2,400^{0} \mathrm{Cpc}$

\begin{tabular}{|c|c|c|}
\hline time & wavelength & absorbance \\
\hline 0 & 537.2 & 0.953 \\
\hline 0.5 & & 0.738 \\
\hline 1 & & 0.714 \\
\hline 1.5 & & 0.513 \\
\hline 2 & & 0.496 \\
\hline 2.5 & & 0.479 \\
\hline 3 & & 0.423 \\
\hline
\end{tabular}

Table:14 Dye in light with $0.02 \mathrm{~g}, 1: 1,500^{\circ} \mathrm{Cpc}$

\begin{tabular}{|c|c|c|}
\hline time & wavelength & absorbance \\
\hline 0 & 537.2 & 0.953 \\
\hline 0.5 & & 0.702 \\
\hline 1 & & 0.605 \\
\hline 1.5 & & 0.531 \\
\hline 2 & & 0.52 \\
\hline 2.5 & & 0.493 \\
\hline 3 & & 0.411 \\
\hline
\end{tabular}

Table:15 Dye in light with $0.02 \mathrm{~g}, 1: 2,500^{\circ} \mathrm{C} \mathrm{pc}$

\begin{tabular}{|c|c|c|}
\hline time & wavelength & absorbance \\
\hline 0 & 537.2 & 0.953 \\
\hline 0.5 & & 0.655 \\
\hline 1 & & 0.557 \\
\hline 1.5 & & 0.527 \\
\hline 2 & & 0.485 \\
\hline 2.5 & & 0.482 \\
\hline 3 & & 0.479 \\
\hline
\end{tabular}

Table:16 Dye in light with $0.02 \mathrm{~g}, 1: 1,600^{\circ} \mathrm{C} \mathrm{pc}$

\begin{tabular}{|c|c|c|}
\hline time & wavelength & absorbance \\
\hline 0 & 537.2 & 0.953 \\
\hline 0.5 & & 0.451 \\
\hline 1 & & 0.406 \\
\hline 1.5 & & 0.371 \\
\hline 2 & & 0.369 \\
\hline 2.5 & & 0.334 \\
\hline 3 & & 0.314 \\
\hline
\end{tabular}


Table:17 Dye in light with $0.02 \mathrm{~g}, 1: 2,600^{\circ} \mathrm{Cpc}$

\begin{tabular}{|c|c|c|}
\hline time & wavelength & absorbance \\
\hline 0 & 537.2 & 0.953 \\
\hline 0.5 & & 0.563 \\
\hline 1 & & 0.532 \\
\hline 1.5 & & 0.49 \\
\hline 2 & & 0.447 \\
\hline 2.5 & & 0.416 \\
\hline 3 & & 0.35 \\
\hline
\end{tabular}

Table:18 Dye in light with $0.03 \mathrm{~g}, 1: 1,400^{\circ} \mathrm{C} \mathrm{pc}$

\begin{tabular}{|c|c|c|}
\hline time & wavelength & absorbance \\
\hline 0 & 537.2 & 0.953 \\
\hline 0.5 & & 0.482 \\
\hline 1 & & 0.47 \\
\hline 1.5 & & 0.386 \\
\hline 2 & & 0.381 \\
\hline 2.5 & & 0.375 \\
\hline 3 & & 0.245 \\
\hline
\end{tabular}

Table:19 Dye in light with $0.03 \mathrm{~g}, 1: 2,400^{\circ} \mathrm{C} \mathrm{pc}$

\begin{tabular}{|c|c|c|}
\hline time & wavelength & absorbance \\
\hline 0 & 537.2 & 0.953 \\
\hline 0.5 & & 0.528 \\
\hline 1 & & 0.464 \\
\hline 1.5 & & 0.431 \\
\hline 2 & & 0.418 \\
\hline 2.5 & & 0.394 \\
\hline 3 & & 0.279 \\
\hline
\end{tabular}

Table:20 Dye in light with $0.03 \mathrm{~g}, 1: 1,500^{\circ} \mathrm{C} \mathrm{pc}$

\begin{tabular}{|c|c|c|}
\hline time & wavelength & absorbance \\
\hline 0 & 537.2 & 0.953 \\
\hline 0.5 & & 0.461 \\
\hline 1 & & 0.325 \\
\hline 1.5 & & 0.32 \\
\hline 2 & & 0.312 \\
\hline 2.5 & & 0.292 \\
\hline 3 & & 0.287 \\
\hline
\end{tabular}

Table:21 Dye in light with $0.03 \mathrm{~g}, 1: 2,500^{0} \mathrm{Cpc}$

\begin{tabular}{|c|c|c|}
\hline time & wavelength & absorbance \\
\hline 0 & 537.2 & 0.953 \\
\hline 0.5 & & 0.418 \\
\hline 1 & & 0.361 \\
\hline 1.5 & & 0.321 \\
\hline 2 & & 0.197 \\
\hline 2.5 & & 0.18 \\
\hline 3 & & 0.164 \\
\hline
\end{tabular}

Table:22 Dye in light with $0.03 \mathrm{~g}, 1: 1,600^{\circ} \mathrm{C} \mathrm{pc}$

\begin{tabular}{|c|c|c|}
\hline time & wavelength & absorbance \\
\hline 0 & 537.2 & 0.953 \\
\hline 0.5 & & 0.455 \\
\hline 1 & & 0.42 \\
\hline 1.5 & & 0.389 \\
\hline 2 & & 0.358 \\
\hline 2.5 & & 0.304 \\
\hline 3 & & 0.227 \\
\hline
\end{tabular}

Table:23 Dye in light with $0.03 \mathrm{~g}, 1: 2,600^{0} \mathrm{Cpc}$

\begin{tabular}{|c|c|c|}
\hline time & wavelength & absorbance \\
\hline 0 & 537.2 & 0.953 \\
\hline 0.5 & & 0.904 \\
\hline 1 & & 0.886 \\
\hline 1.5 & & 0.836 \\
\hline 2 & & 0.73 \\
\hline 2.5 & & 0.717 \\
\hline 3 & & 0.692 \\
\hline
\end{tabular}

\section{Ultraviolet spectroscopy of the Dye Samples}

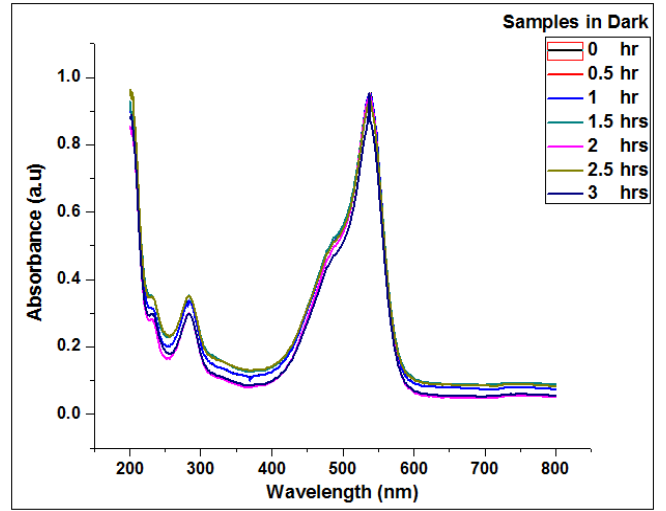

Fig.1 Dye samples in the dark 


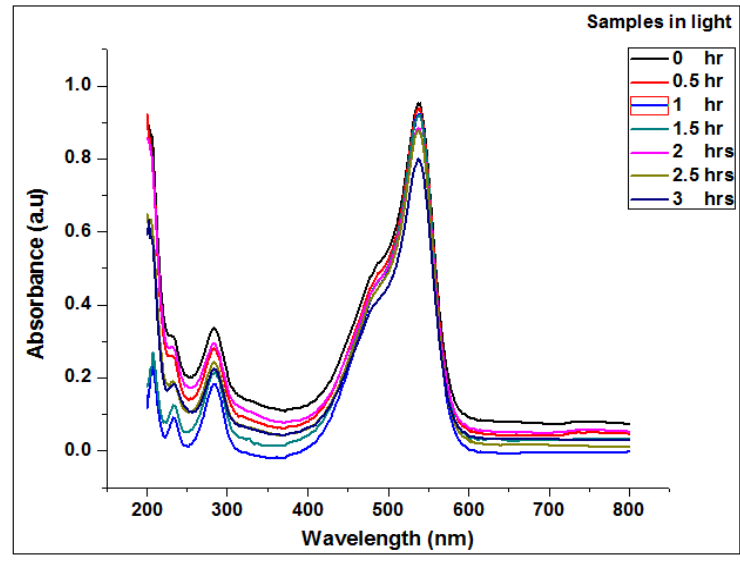

Fig.2 Dye samples in light

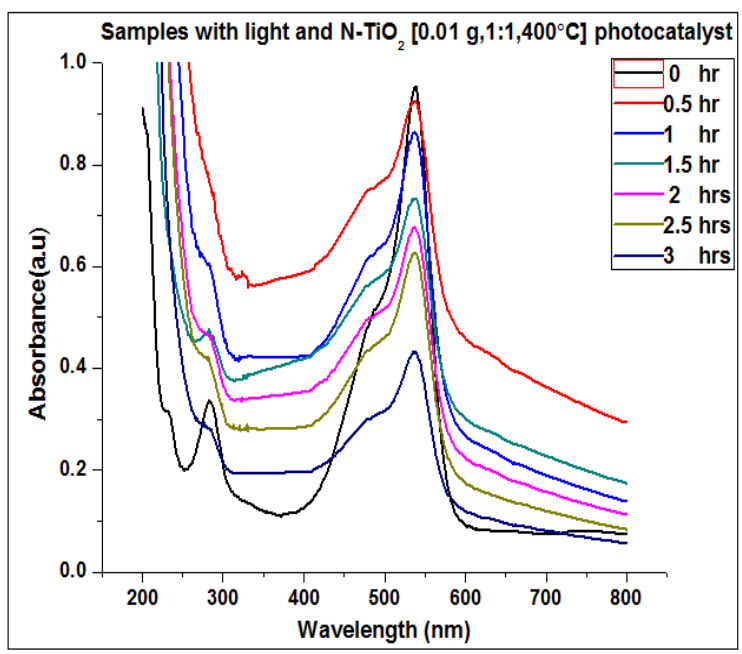

Fig.3 Dye samples with light and $0.01 \mathrm{~g} .1: 1,400^{\circ} \mathrm{C} \mathrm{pc}$

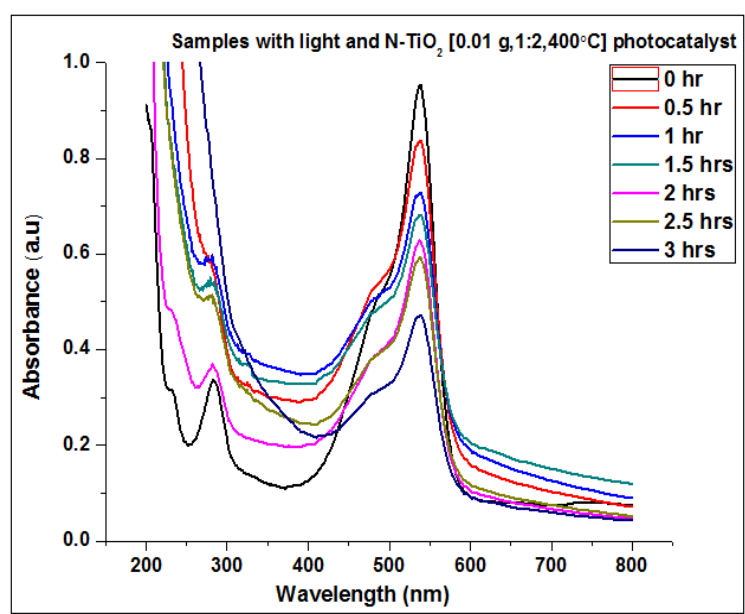

Fig.4 Dye samples with light and $0.01 \mathrm{~g} \cdot 1: 2,400^{\circ} \mathrm{C} \mathrm{pc}$

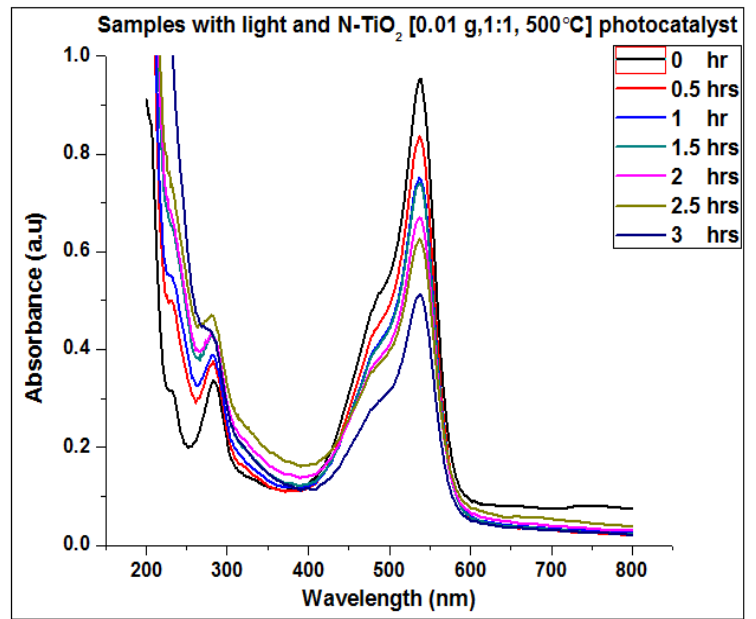

Fig.5 Dye samples with light and $0.01 \mathrm{~g} .1: 1,500^{\circ} \mathrm{C} \mathrm{pc}$

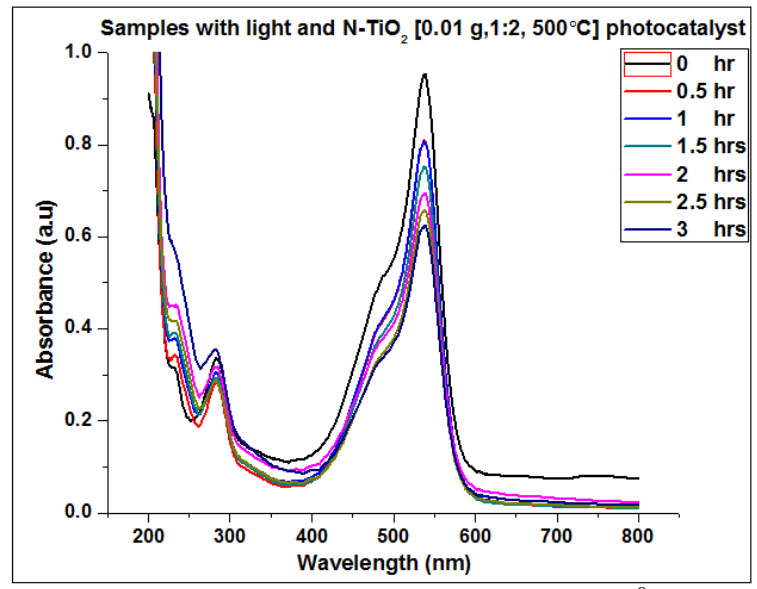

Fig.6 Dye samples with light and $0.01 \mathrm{~g} .1: 2,500^{\circ} \mathrm{C} \mathrm{pc}$

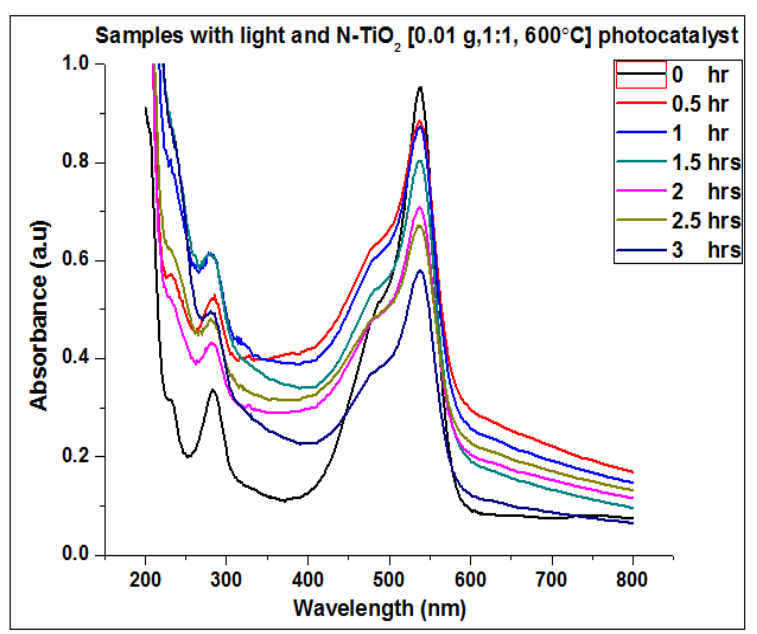

Fig.7 Dye samples with light and $0.01 \mathrm{~g} .1: 1,600^{\circ} \mathrm{C} \mathrm{pc}$ 


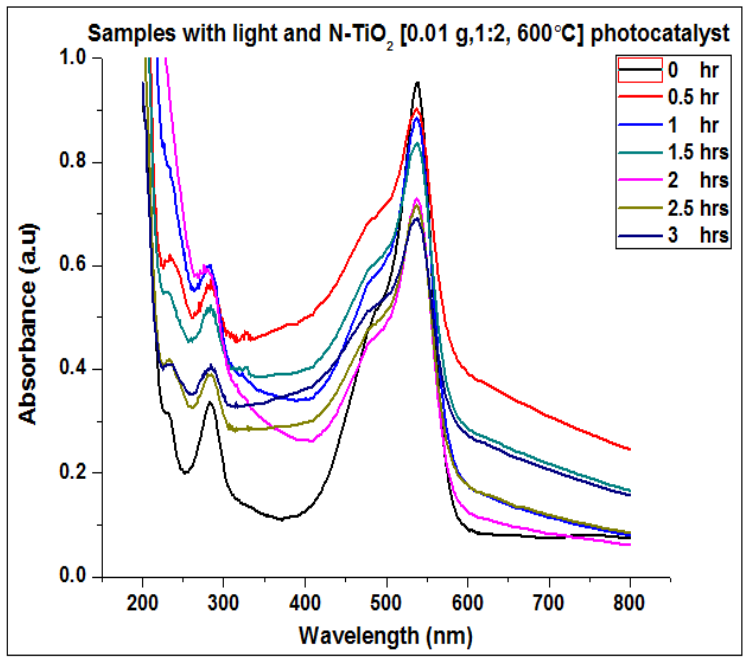

Fig.8 Dye samples with light and $0.01 \mathrm{~g} .1: 2,600^{\circ} \mathrm{C} \mathrm{pc}$

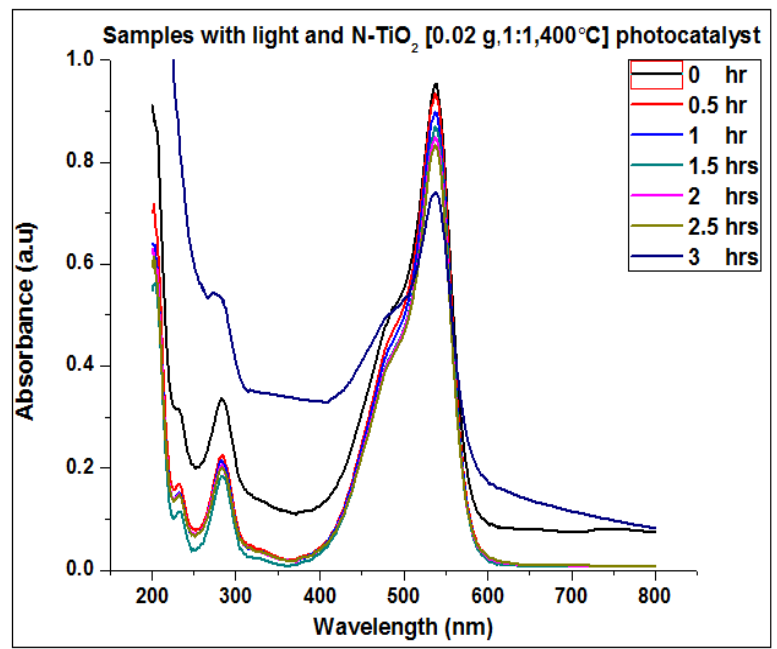

Fig.9 Dye samples with light and $0.02 \mathrm{~g} .1: 1,400^{\circ} \mathrm{C}$ pc

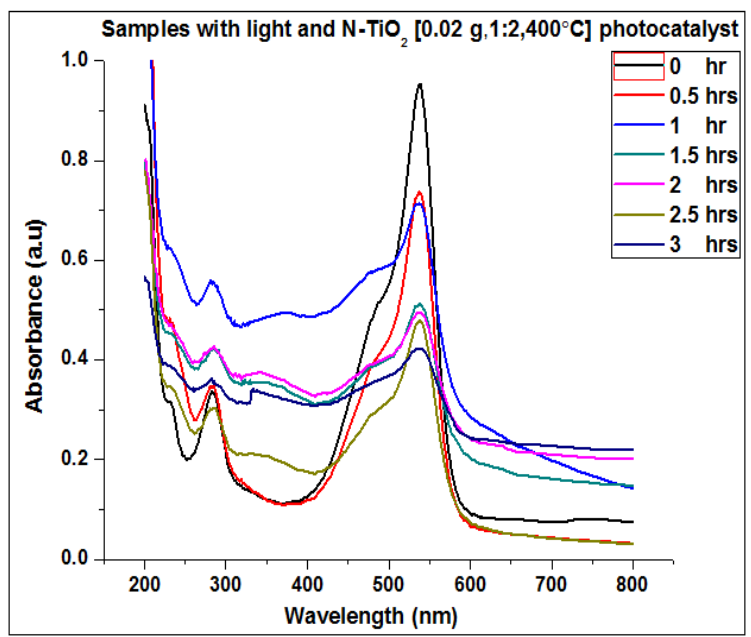

Fig.10 Dye samples with light and $0.02 \mathrm{~g} .1: 2,400^{\circ} \mathrm{C} \mathrm{pc}$

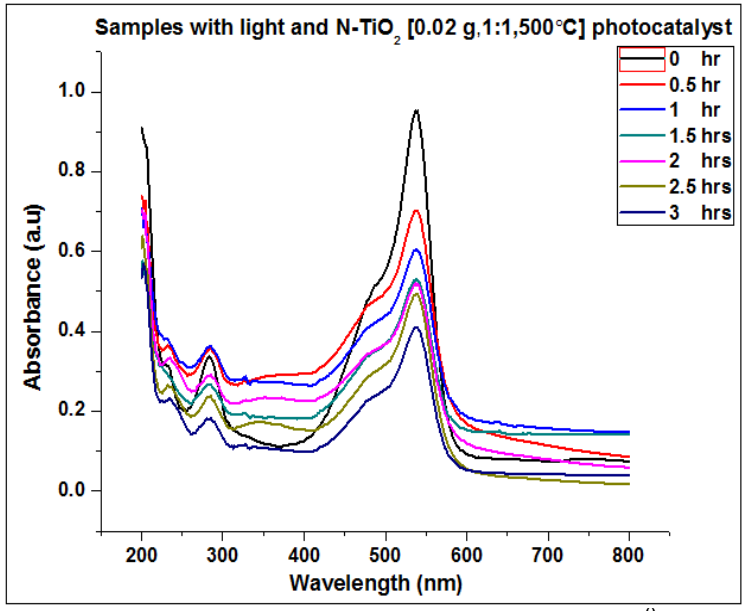

Fig.11 Dye samples with light and $0.02 \mathrm{~g} \cdot 1: 1,500^{\circ} \mathrm{C} \mathrm{pc}$

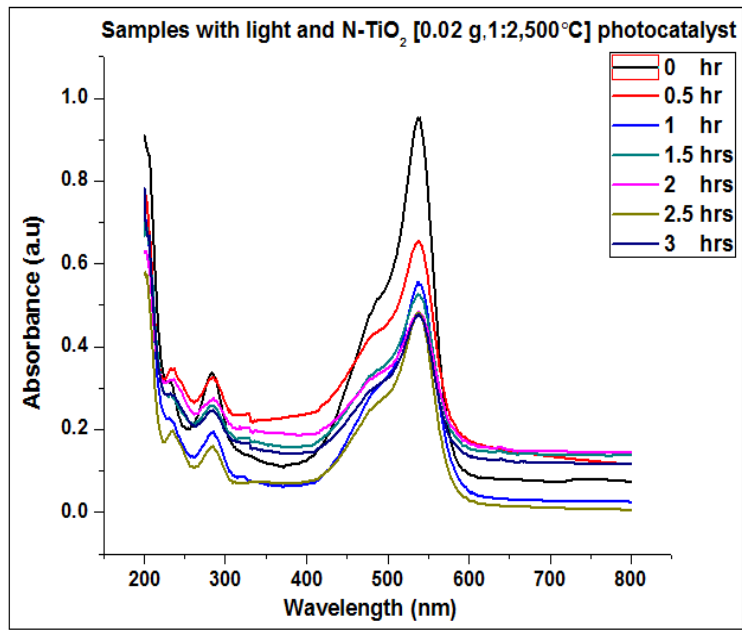

Fig.12 Dye samples with light and $0.02 \mathrm{~g}, 1: 2,500^{\circ} \mathrm{C} \mathrm{pc}$

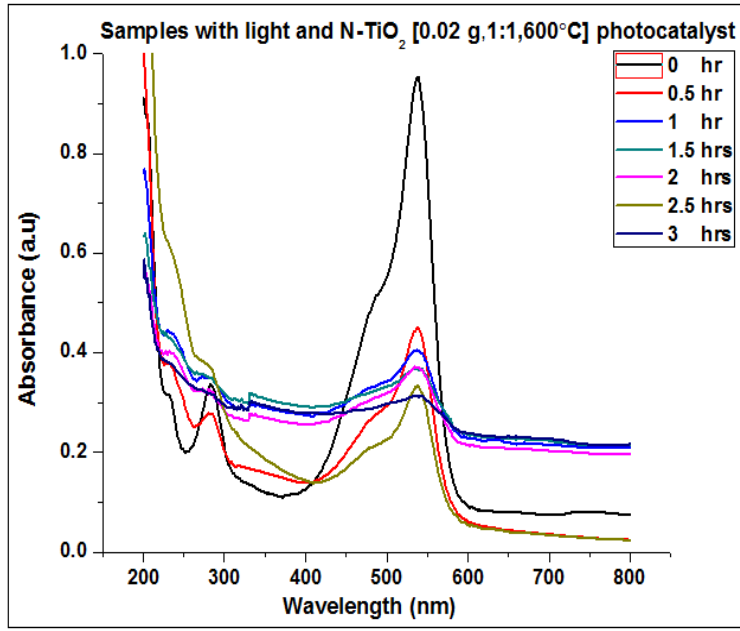

Fig.13 Dye samples with light and $0.02 \mathrm{~g}, 1: 1,600^{\circ} \mathrm{C} \mathrm{pc}$ 


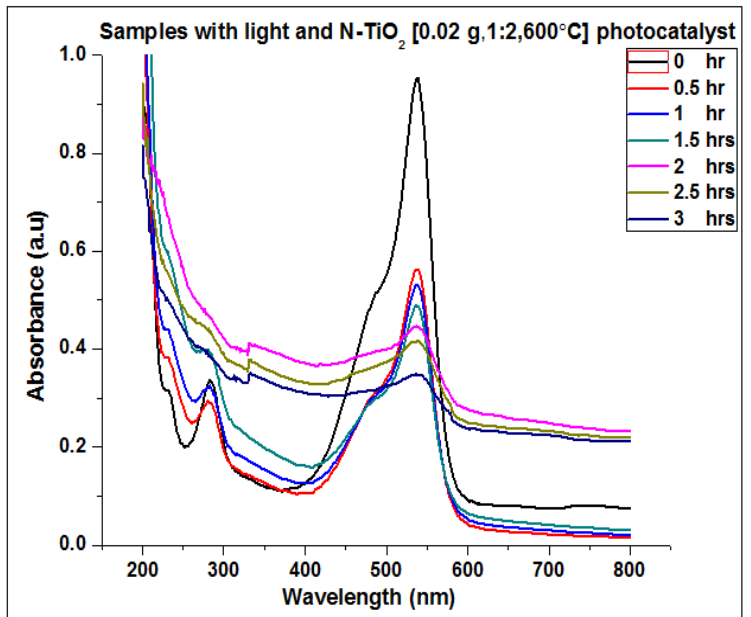

Fig.14 Dye samples with light and $0.02 \mathrm{~g}, 1: 2,600^{\circ} \mathrm{C} \mathrm{pc}$

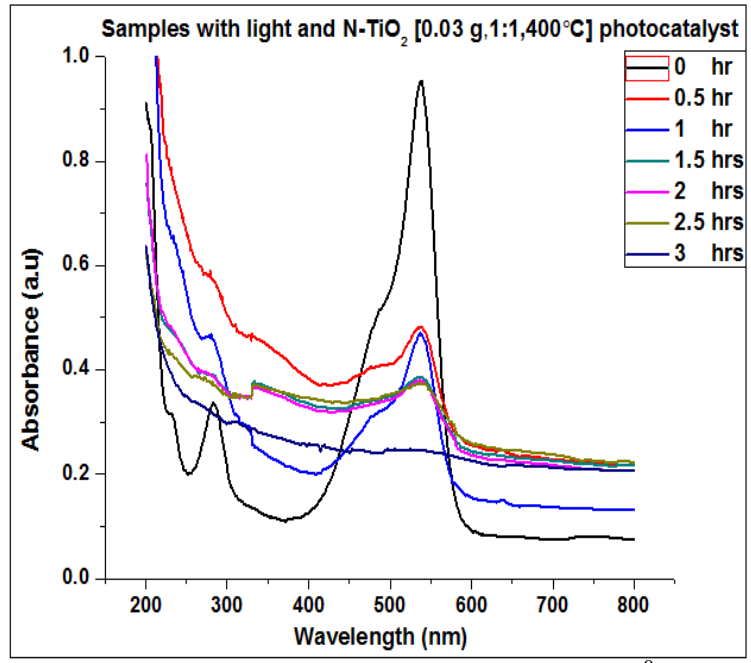

Fig.15 Dye samples with light and $0.03 \mathrm{~g}, 1: 1,400^{\circ} \mathrm{C} \mathrm{pc}$

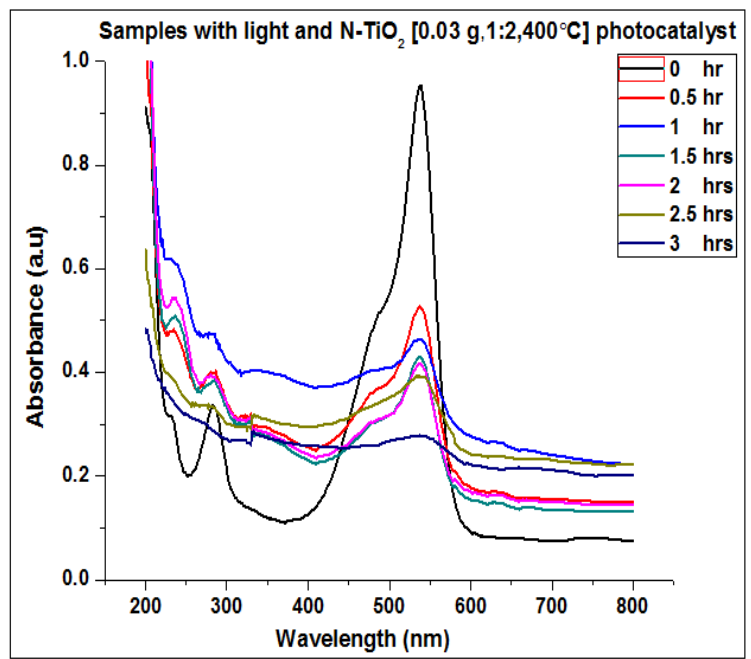

Fig.16 Dye samples with light and $0.03 \mathrm{~g}, 1: 2,400^{\circ} \mathrm{C} \mathrm{pc}$

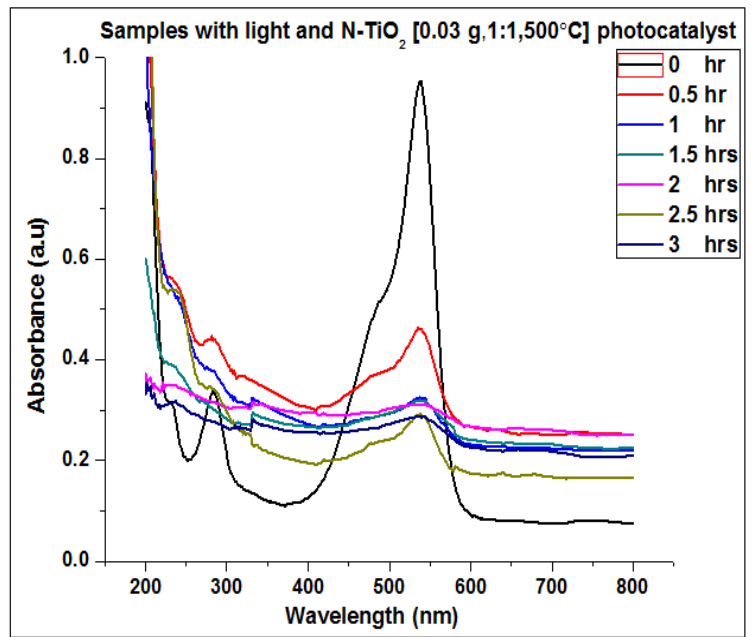

Fig.17 Dye samples with light and $0.03 \mathrm{~g}, 1: 1,500^{\circ} \mathrm{C} \mathrm{pc}$

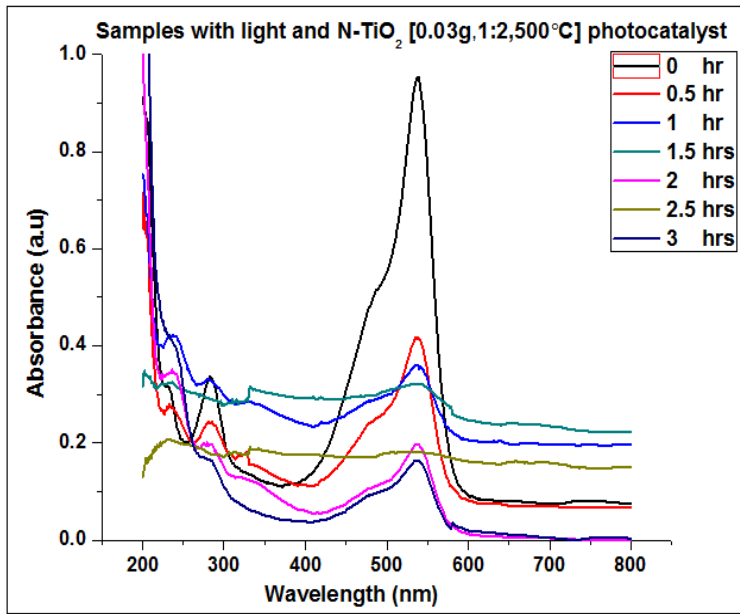

Fig.18 Dye samples with light and $0.03 \mathrm{~g}, 1: 2,500^{\circ} \mathrm{C} \mathrm{pc}$

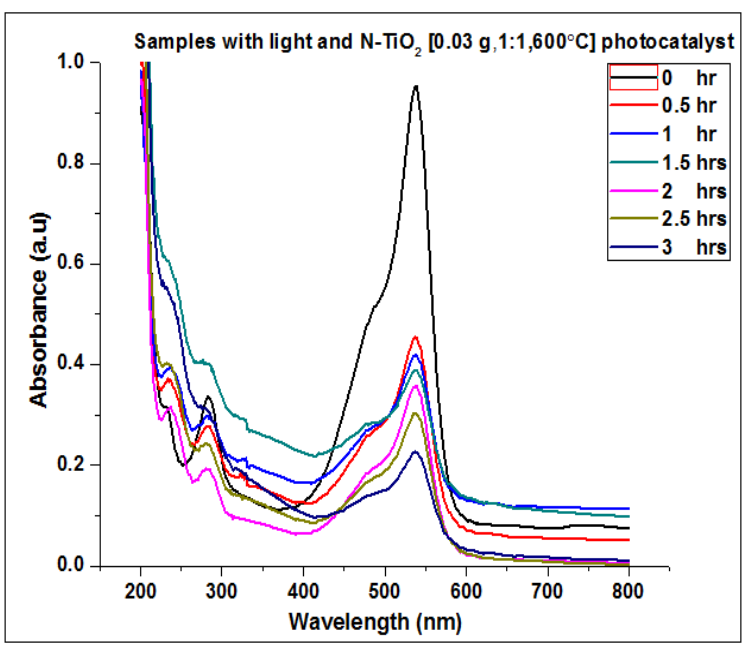

Fig.19 Dye samples with light and $0.03 \mathrm{~g}, 1: 1,600^{\circ} \mathrm{C} \mathrm{pc}$ 


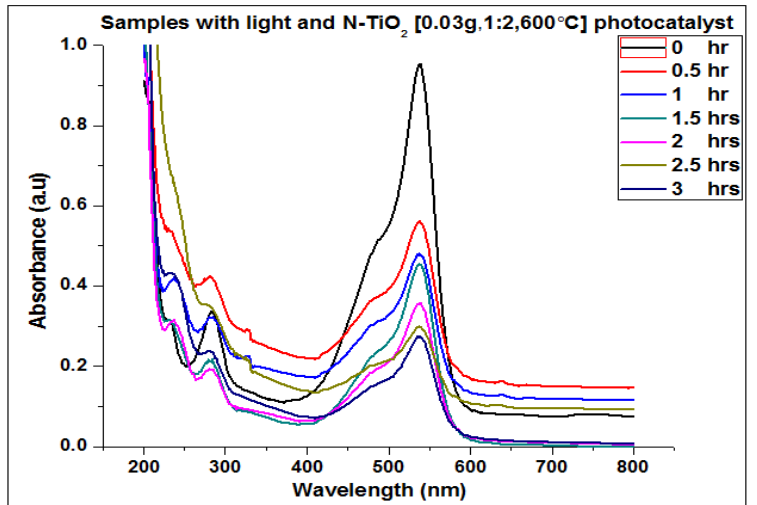

Fig.20 Dye samples with light and $0.03 \mathrm{~g}, 1: 2,600^{\circ} \mathrm{C} \mathrm{pc}$

Energy Dispersive X-ray Analysis of the Dye samples

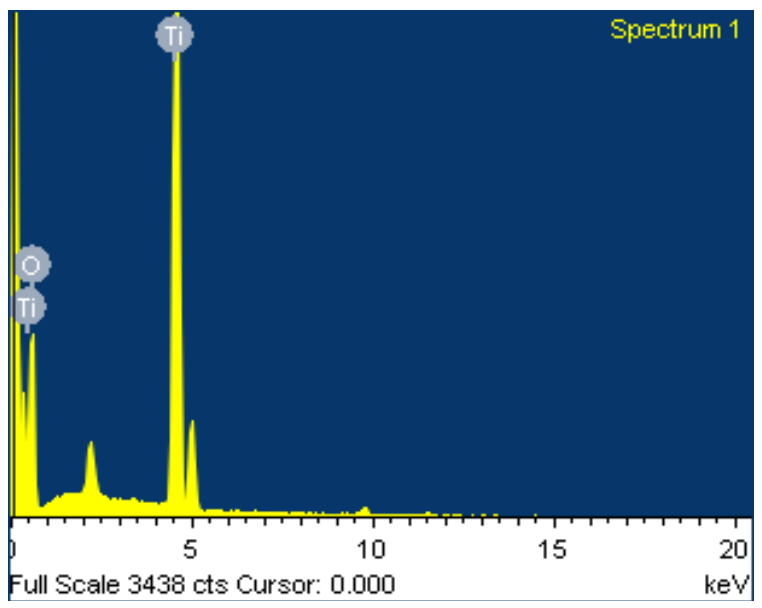

Fig.21 EDAX of $1: 1,400^{\circ} \mathrm{C}$ Photocatalyst

Inca energy $250 \ln 2$ closed model - Oxford U.K instrument

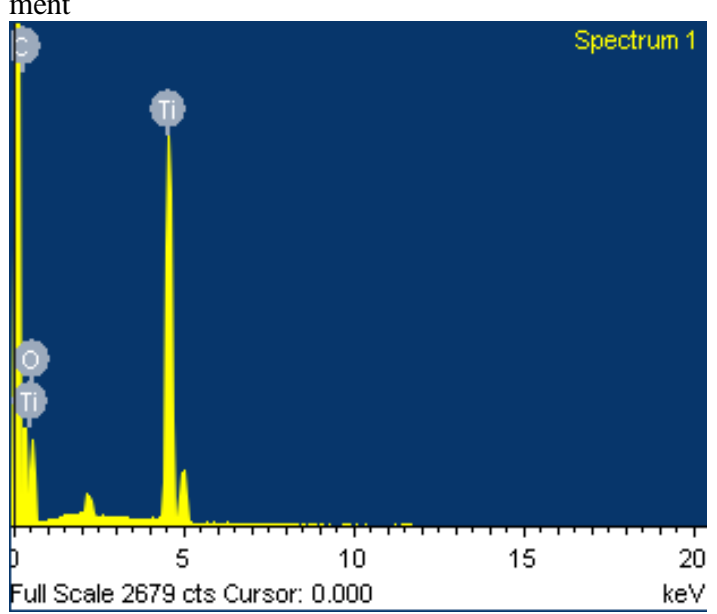

Fig.22 EDAX of $1: 2,400^{\circ} \mathrm{C}$ Photocatalyst

\begin{tabular}{|l|l|l|}
\hline Element & Intensity corrl. & Atomic \% \\
\hline $\mathrm{C}$ & 0.893 & 32.65 \\
\hline $\mathrm{O}$ & 0.3384 & 51.71 \\
\hline $\mathrm{Ti}$ & 0.872 & 15.64 \\
\hline
\end{tabular}

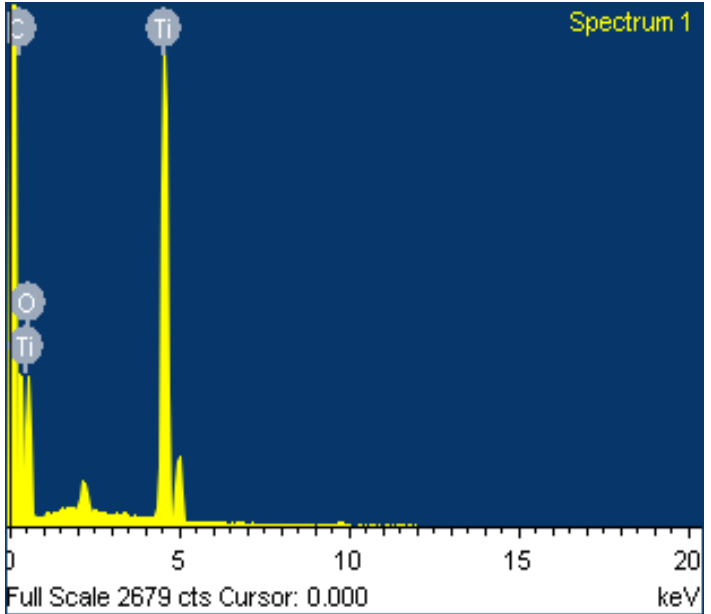

Fig.23 EDAX of $1: 1,500^{\circ} \mathrm{C}$ Photocatalyst

\begin{tabular}{|l|l|l|}
\hline Element & Intensity corrl. & Atomic \% \\
\hline $\mathrm{C}$ & 0.9038 & 32.82 \\
\hline $\mathrm{O}$ & 0.3677 & 53.96 \\
\hline $\mathrm{Ti}$ & 0.8637 & 13.22 \\
\hline
\end{tabular}

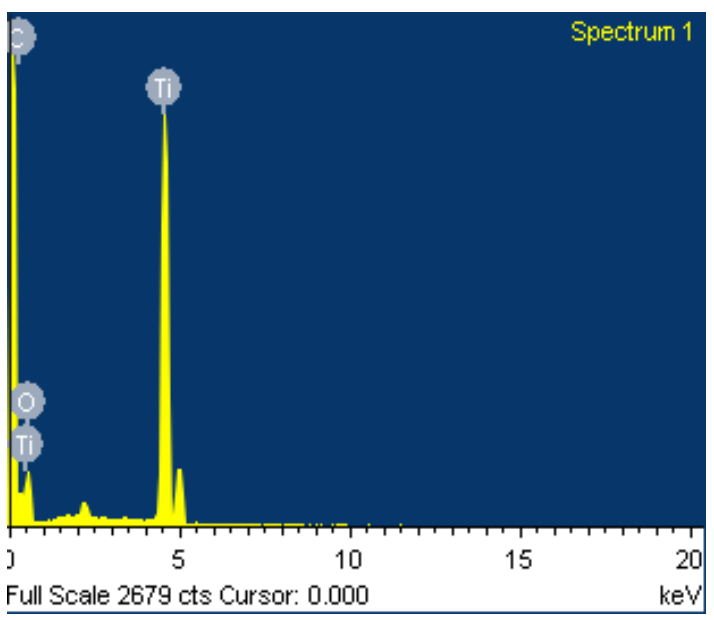

Fig.24 EDAX of $1: 2,500^{\circ} \mathrm{C}$ Photocatalyst

\begin{tabular}{|c|c|c|}
\hline Element & Intensity corrl. & Atomic \% \\
\hline $\mathrm{C}$ & 0.8167 & 17.09 \\
\hline $\mathrm{O}$ & 0.2957 & 57.21 \\
\hline $\mathrm{Ti}$ & 0.9012 & 25.70 \\
\hline
\end{tabular}




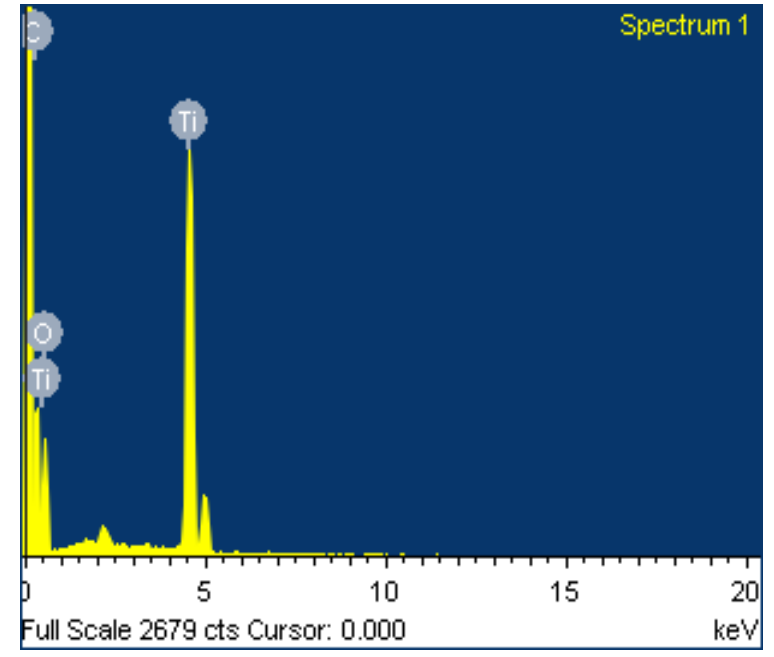

Fig. 25 EDAX of $1: 1,600^{\circ} \mathrm{C}$ Photocatalyst

\begin{tabular}{|l|l|l|}
\hline Element & Intensity corrl. & Atomic \% \\
\hline $\mathrm{C}$ & 0.8749 & 30.81 \\
\hline $\mathrm{O}$ & 0.3141 & 50.46 \\
\hline $\mathrm{Ti}$ & 0.8819 & 18.73 \\
\hline
\end{tabular}

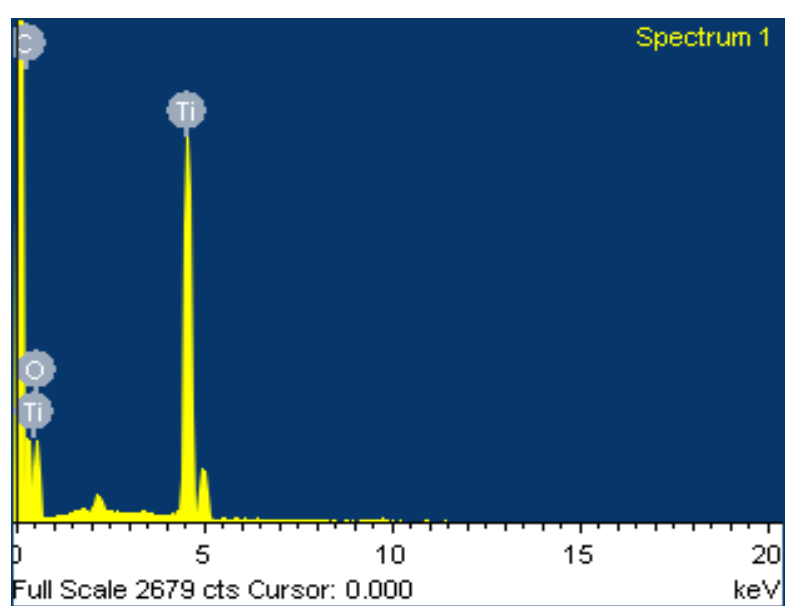

Fig.26 EDAX of $1: 2,600^{\circ} \mathrm{C}$ Photocatalyst

\begin{tabular}{|l|l|l|}
\hline Element & Intensity corrl. & Atomic \% \\
\hline $\mathrm{C}$ & 0.8768 & 30.35 \\
\hline $\mathrm{O}$ & 0.3246 & 51.97 \\
\hline $\mathrm{Ti}$ & 0.8787 & 17.68 \\
\hline
\end{tabular}

Infrared spectroscopy of the dye samples

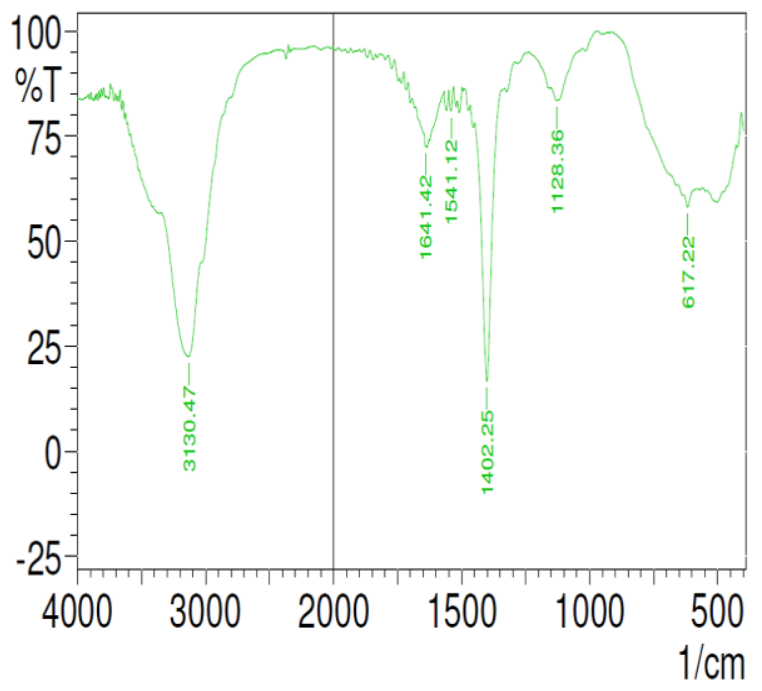

Fig.27 IR of $1: 1,400^{0} \mathrm{C}$ Photocatalyst

\begin{tabular}{|l|l|l|}
\hline Peak & Intensity & $\begin{array}{l}\text { Correction in- } \\
\text { tensity }\end{array}$ \\
\hline 1402.25 & 16.677 & 64.736 \\
\hline
\end{tabular}

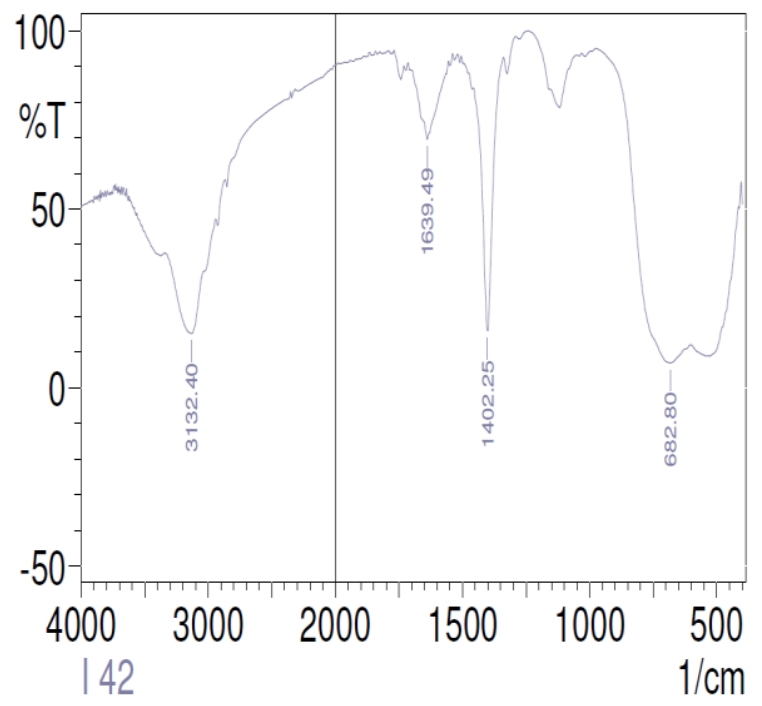

Fig.28 IR of $1: 2,400^{\circ} \mathrm{C}$ Photocatalyst

\begin{tabular}{|l|l|l|}
\hline Peak & Intensity & $\begin{array}{l}\text { Correction in- } \\
\text { tensity }\end{array}$ \\
\hline 1402.25 & 68.659 & 23.933 \\
\hline
\end{tabular}




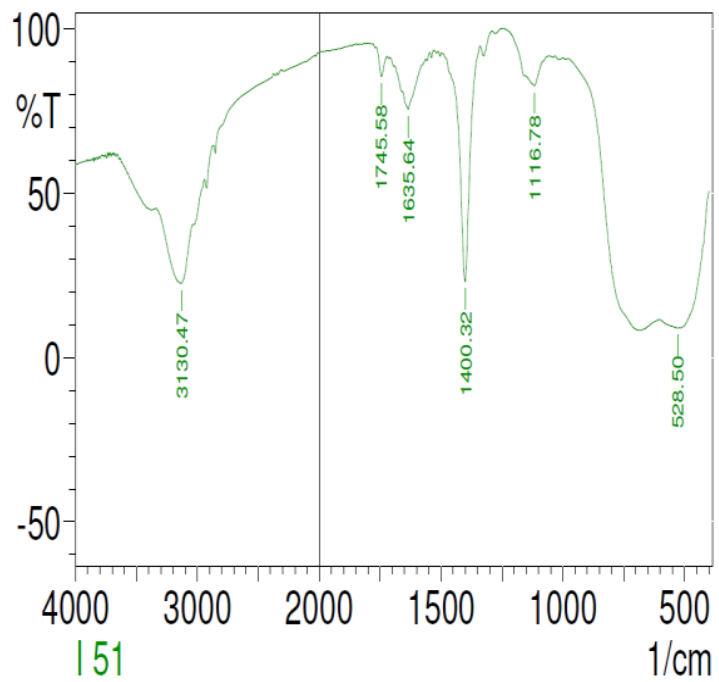

Fig.29 IR of $1: 1,500^{0} \mathrm{C}$ Photocatalyst

\begin{tabular}{|l|l|l|}
\hline Peak & Intensity & $\begin{array}{l}\text { Correction in- } \\
\text { tensity }\end{array}$ \\
\hline 1400.32 & 23.045 & 70.639 \\
\hline
\end{tabular}

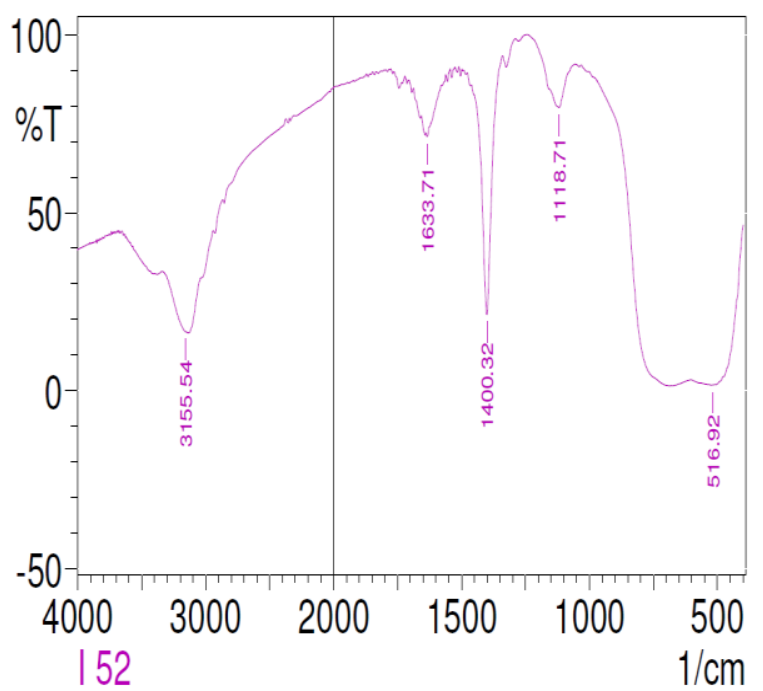

Fig.30 IR of $1: 2,500^{\circ} \mathrm{C}$ Photocatalyst

\begin{tabular}{|l|l|l|}
\hline Peak & Intensity & $\begin{array}{l}\text { Correction } \\
\text { intensity }\end{array}$ \\
\hline 1400.32 & 21.454 & 66.691 \\
\hline
\end{tabular}

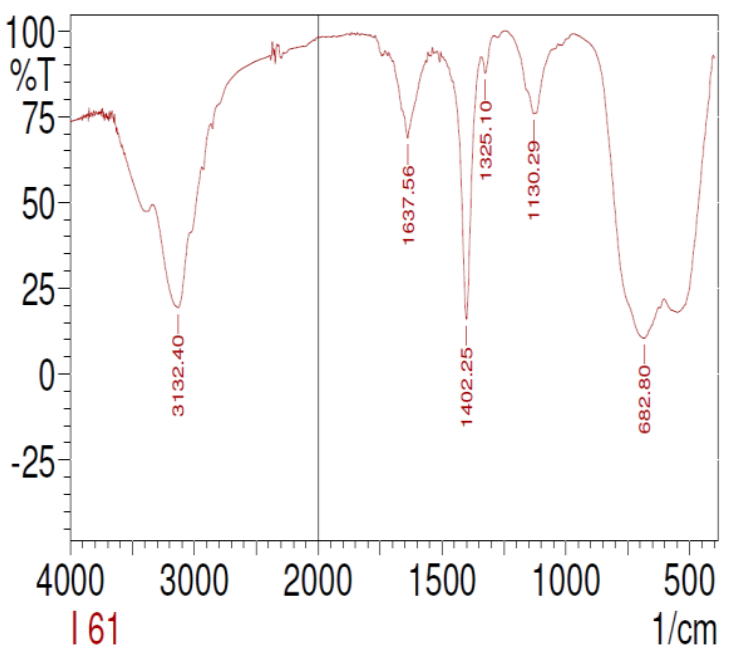

Fig. 31 IR of $1: 1,600^{\circ} \mathrm{C}$ Photocatalyst

\begin{tabular}{|l|l|l|}
\hline Peak & Intensity & $\begin{array}{l}\text { Correction in- } \\
\text { tensity }\end{array}$ \\
\hline 1402.25 & 16.002 & 72.644 \\
\hline
\end{tabular}

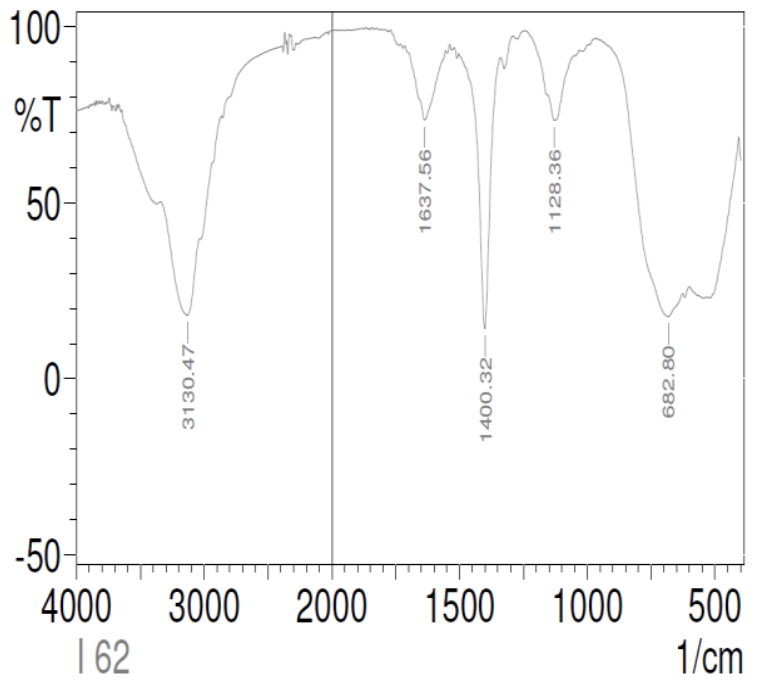

Fig.32 IR of $1: 2,600^{0} \mathrm{C}$ Photocatalyst

\begin{tabular}{|l|l|l|}
\hline Peak & Intensity & $\begin{array}{l}\text { Correction in- } \\
\text { tensity }\end{array}$ \\
\hline 1400.32 & 14.182 & 77.386 \\
\hline
\end{tabular}




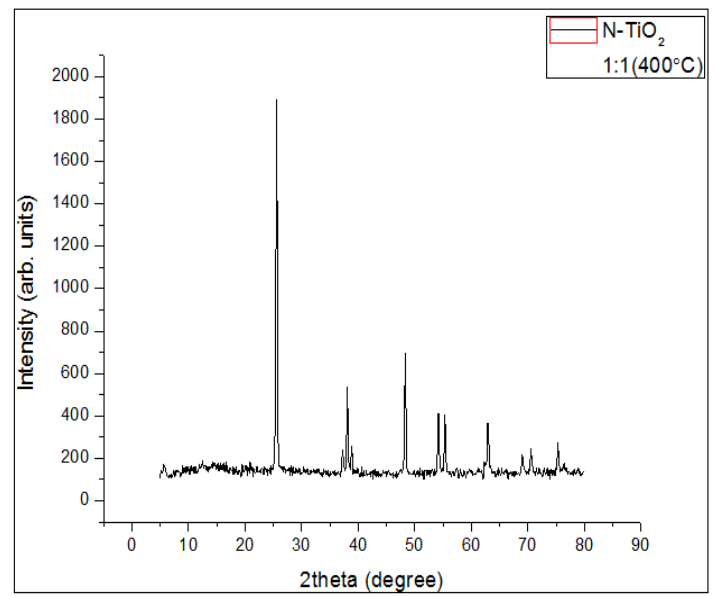

Fig.33 XRD of $1: 1,400^{0} \mathrm{C}$ Photocatalyst

\begin{tabular}{|l|l|l|}
\hline Strongest peak & 2 theta(degree) & Intensity counts \\
\hline 1 & 25.5523 & 1079 \\
\hline
\end{tabular}

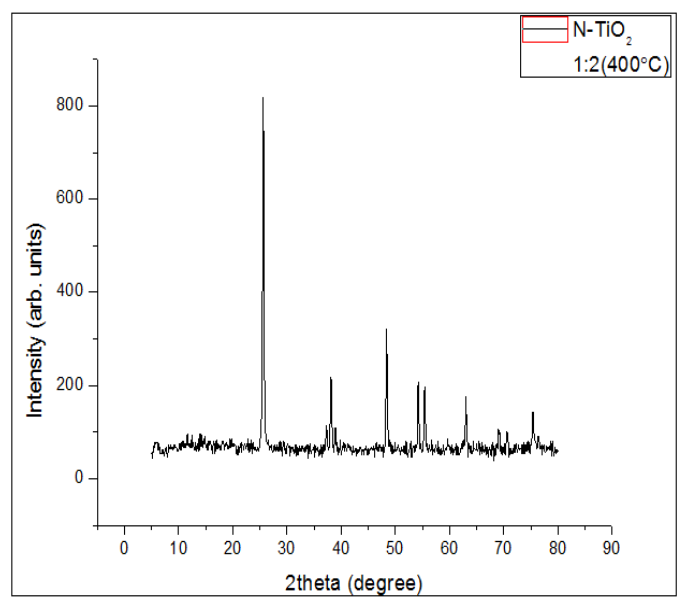

Fig.34 XRD of $1: 2,400^{\circ} \mathrm{C}$ Photocatalyst

\begin{tabular}{|l|l|l|}
\hline Strongest peak & 2theta(degree) & Intensity counts \\
\hline 1 & 25.6002 & 498 \\
\hline
\end{tabular}

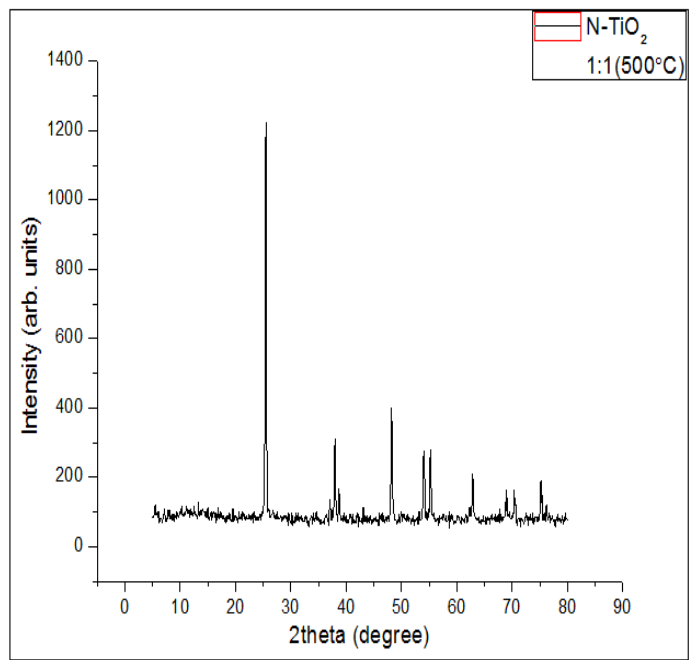

Fig. 35 XRD of $1: 1,500^{\circ} \mathrm{C}$ Photocatalyst

\begin{tabular}{|l|l|l|}
\hline Strongest peak & 2 theta(degree) & Intensity counts \\
\hline 1 & 25.4366 & 520 \\
\hline
\end{tabular}

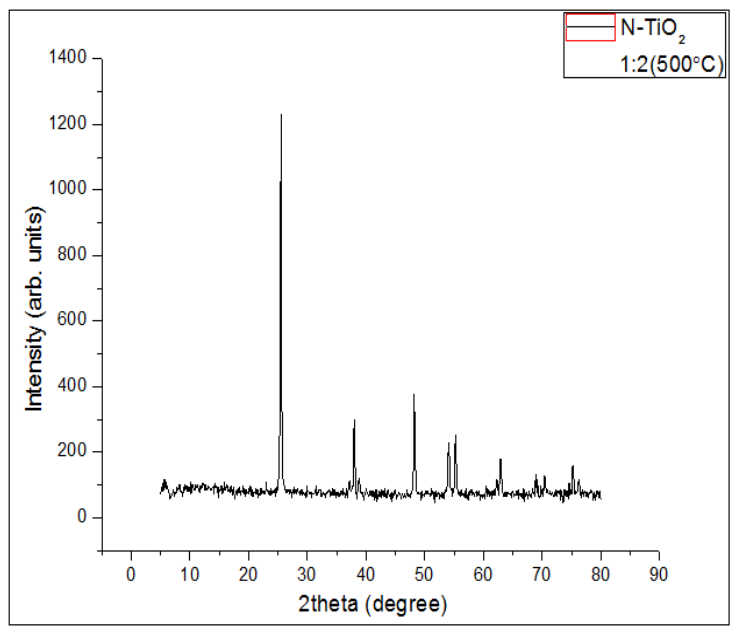

Fig.36 XRD of $1: 2,500^{\circ} \mathrm{C}$ Photocatalyst

\begin{tabular}{|l|l|l|}
\hline Strongest peak & 2theta(degree) & Intensity counts \\
\hline 1 & 25.4600 & 474 \\
\hline
\end{tabular}




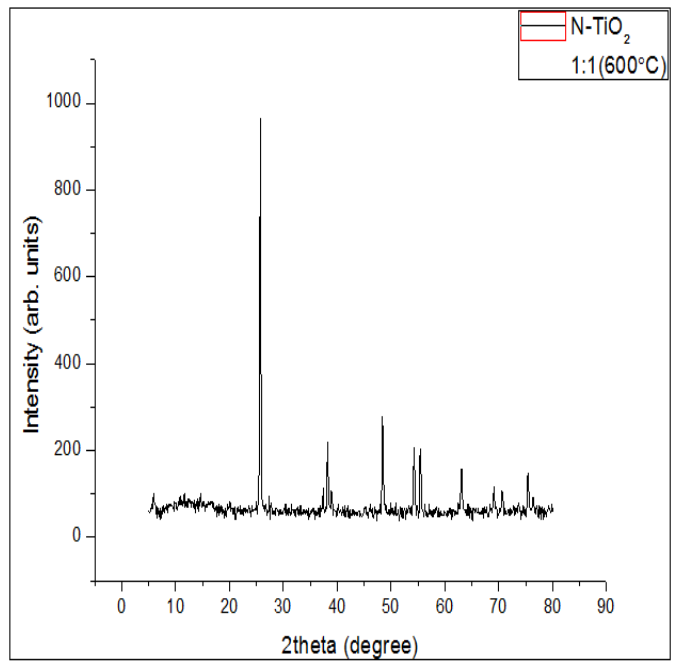

Fig. 37 XRD of $1: 1,600^{\circ} \mathrm{C}$ Photocatalyst

\begin{tabular}{|l|l|l|}
\hline Strongest peak & 2 theta(degree) & Intensity counts \\
\hline 1 & 28.6936 & 399 \\
\hline
\end{tabular}

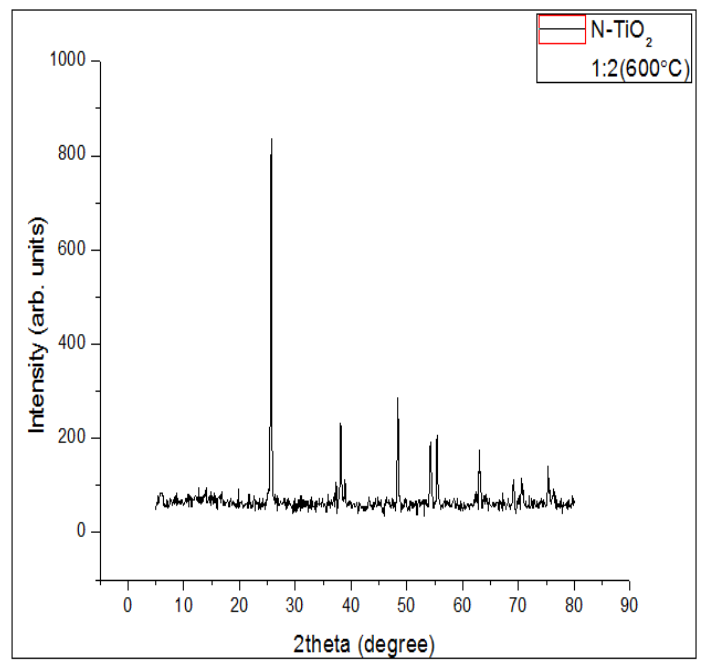

Fig. 38 XRD of $1: 2,600^{\circ} \mathrm{C}$ Photocatalyst

\begin{tabular}{|l|l|l|}
\hline Strongest peak & 2 theta(degree) & Intensity counts \\
\hline 1 & 25.6300 & 357 \\
\hline
\end{tabular}

Scanning Electron Microscopic Images of the dye Samples

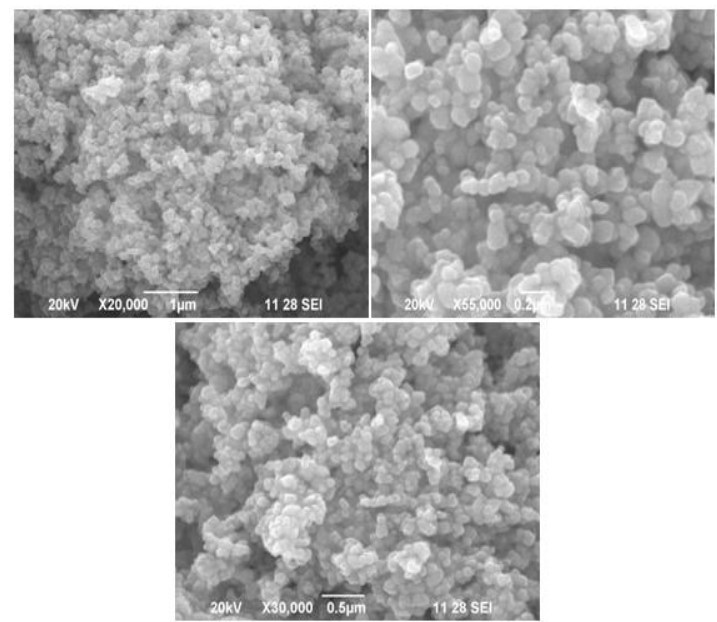

Fig.39 SEM of $1: 1,400^{\circ} \mathrm{C}$ Photocatalyst

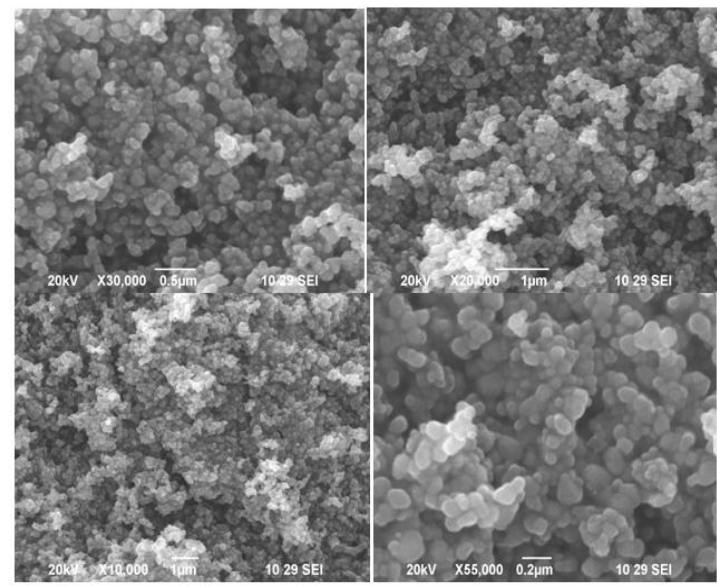

Fig.40 SEM of $1: 2,400^{\circ} \mathrm{C}$ Photocatalyst
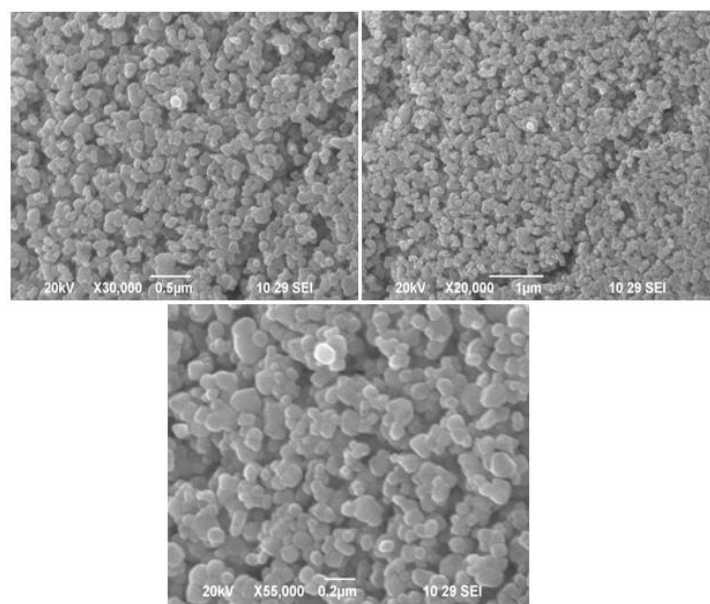

Fig.41 SEM of $1: 1,500^{\circ} \mathrm{C}$ Photocatalyst 


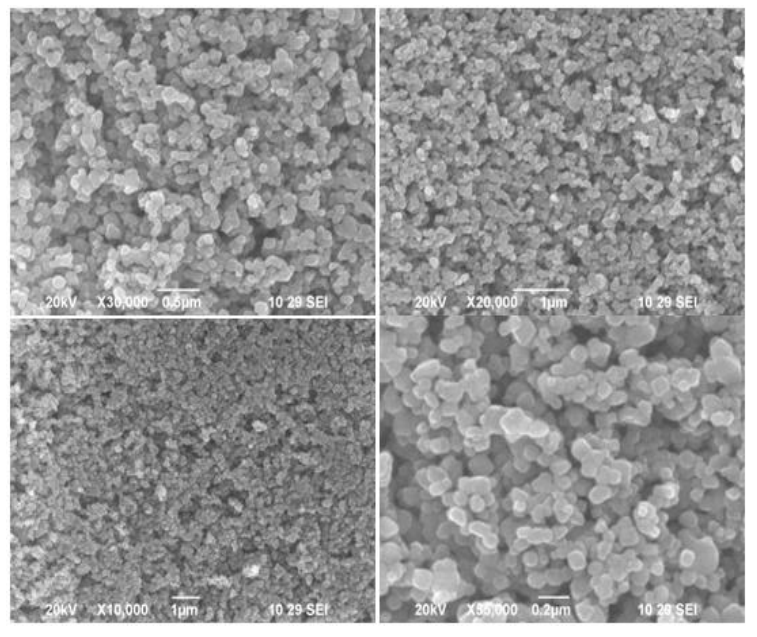

Fig.42 SEM of $1: 2,500^{\circ} \mathrm{C}$ Photocatalyst

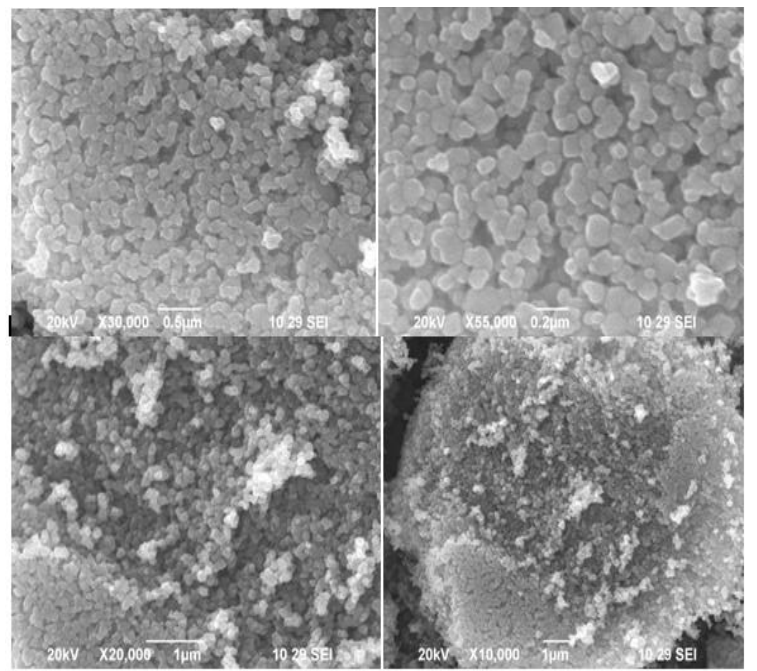

Fig.43 SEM of $1: 1,600^{\circ} \mathrm{C}$ Photocatalyst

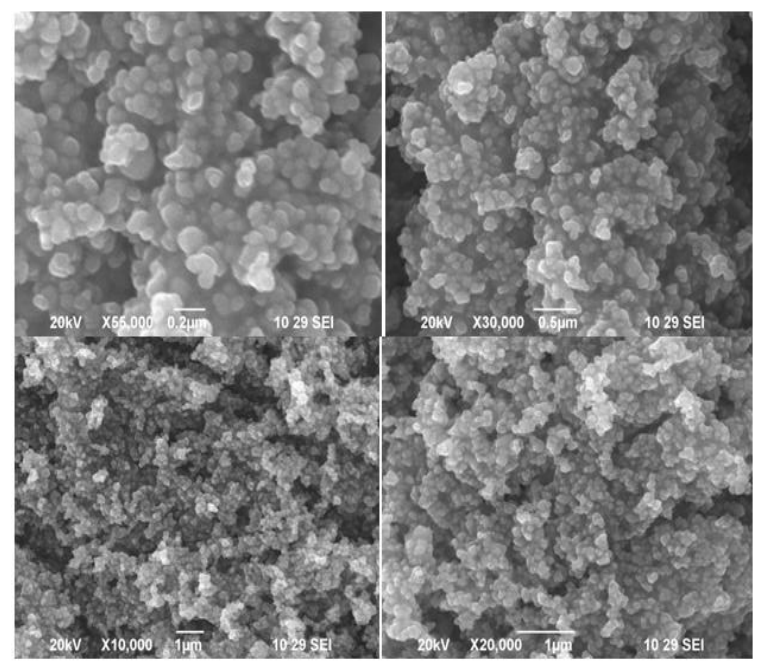

Fig.44 SEM of $1: 2,600^{\circ} \mathrm{C}$ Photocatalyst

Table 1, Fig. 1 discusses the degradation using photocatalyst on Basic Fuchsin dye from the initial value 0.953 ; it reveals that the photodegradation is same as the initial value in the dark. Table 2-4 re- veals less degradation rate of the dye using the photocatalyst in the dark. Table 5, Fig. 2 discusses the degradation using photocatalyst on Basic Fuchsin dye, reveals that the dye has photodegraded from 0.953 to 0.800 in light alone. Table 6, Fig. 3 discusses the degradation using photocatalyst on Basic Fuchsin dye, reveals that the dye has photodegraded from 0.953 to 0.432 in light with $0.01 \mathrm{~g}, 1: 1,400^{\circ} \mathrm{C}$, $\mathrm{N}-\mathrm{TiO}_{2}$ photocatalyst. Table 7 , Fig. 4 discusses the degradation using photocatalyst on Basic Fuchsin dye, reveals that the dye has photodegraded from 0.953 to 0.472 in light with $0.01 \mathrm{~g}, 1: 2,400^{\circ} \mathrm{C}, \mathrm{N}-$ $\mathrm{TiO}_{2}$ photocatalyst. Table 8, Fig. 5 discusses the degradation using photocatalyst on Basic Fuchsin dye, reveals that the dye has photodegraded from 0.953 to 0.513 in light with $0.01 \mathrm{~g}, 1: 1,500^{\circ} \mathrm{C}, \quad \mathrm{N}-\mathrm{TiO}_{2}$ photocatalyst. Table 9, Fig. 6 discusses the degradation using photocatalyst on Basic Fuchsin dye, reveals that the dye has photodegraded from 0.953 to 0.624 in light with $0.01 \mathrm{~g}, 1: 2,500^{\circ} \mathrm{C}, \quad \mathrm{N}-\mathrm{TiO}_{2}$ photocatalyst. Table 10, Fig. 7 discusses the degradation using photocatalyst on Basic Fuchsin dye, reveals that the dye has photodegraded from 0.953 to 0.580 in light with $0.01 \mathrm{~g}, 1: 1,600^{\circ} \mathrm{C}, \mathrm{N}-\mathrm{TiO}_{2}$ photocatalyst. Table 11, Fig. 8 discusses the degradation using photocatalyst on Basic Fuchsin dye, reveals that the dye has photodegraded from 0.953 to 0.692 in light with $0.01 \mathrm{~g}, 1: 2,600^{\circ} \mathrm{C}, \quad \mathrm{N}-\mathrm{TiO}_{2}$ photocatalyst. Table 12, Fig. 9 discusses the degradation using photocatalyst on Basic Fuchsin dye, reveals that the dye has photodegraded from 0.953 to 0.741 in light with $0.02 \mathrm{~g}, 1: 1,400^{\circ} \mathrm{C}, \quad \mathrm{N}-\mathrm{TiO}_{2}$ photocatalyst. Table 13, Fig. 10 discusses the degradation using photocatalyst on Basic Fuchsin dye, reveals that the dye has photodegraded from 0.953 to 0.423 in light with $0.02 \mathrm{~g}, 1: 2,400^{\circ} \mathrm{C}, \quad \mathrm{N}-\mathrm{TiO}_{2}$ photocatalyst. Table 14, Fig. 11 discusses the degradation using photocatalyst on Basic Fuchsin dye, reveals that the dye has photodegraded from 0.953 to 0.411 in light with $0.02 \mathrm{~g}, 1: 1,500^{\circ} \mathrm{C}, \quad \mathrm{N}-\mathrm{TiO}_{2}$ photocatalyst. Table 15, Fig. 12 discusses the degradation using photocatalyst on Basic Fuchsin dye, reveals that the dye has photodegraded from 0.953 to 0.479 in light with $0.02 \mathrm{~g}, 1: 2,500^{\circ} \mathrm{C}, \quad \mathrm{N}-\mathrm{TiO}_{2}$ photocatalyst. Table 16, Fig. 13 discusses the degradation using photocatalyst on Basic Fuchsin dye, reveals that the dye has photodegraded from 0.953 to 0.314 in light with $0.02 \mathrm{~g}, 1: 1,600^{\circ} \mathrm{C}, \quad \mathrm{N}-\mathrm{TiO}_{2}$ photocatalyst. Table 17, Fig. 14 discusses the degradation using photocatalyst on Basic Fuchsin dye, reveals that the dye has photodegraded from 0.953 to 0.35 in light with $0.02 \mathrm{~g}, 1: 2,600^{\circ} \mathrm{C}, \quad \mathrm{N}-\mathrm{TiO}_{2}$ photocatalyst. Table 18, Fig. 15 discusses the degradation using photocatalyst on Basic Fuchsin dye, reveals that the dye has photodegraded from 0.953 to 0.245 in light with $0.03 \mathrm{~g}, 1: 1,400^{\circ} \mathrm{C}, \quad \mathrm{N}-\mathrm{TiO}_{2}$ photocatalyst. Table 19, Fig. 16 discusses the degradation using photocatalyst on Basic Fuchsin dye, reveals that the dye has photodegraded from 0.953 to 0.279 in light with $0.03 \mathrm{~g}, 1: 2,400^{\circ} \mathrm{C}, \quad \mathrm{N}-\mathrm{TiO}_{2}$ 
photocatalyst. Table 20, Fig. 17 discusses the degradation using photocatalyst on Basic Fuchsin dye, reveals that the dye has photodegraded from 0.953 to 0.287 in light with $0.03 \mathrm{~g}, 1: 1,500^{\circ} \mathrm{C}, \quad \mathrm{N}-\mathrm{TiO}_{2}$ photocatalyst. Table 21, Fig. 18 discusses the degradation using photocatalyst on Basic Fuchsin dye, reveals that the dye has photodegraded from 0.953 to 0.164 in light with $0.03 \mathrm{~g}, 1: 2,500^{\circ} \mathrm{C}, \quad \mathrm{N}-\mathrm{TiO}_{2}$ photocatalyst. Table 22, Fig. 19 discusses the degradation using photocatalyst on Basic Fuchsin dye, reveals that the dye has photodegraded from 0.953 to 0.227 in light with $0.03 \mathrm{~g}, 1: 1,600^{\circ} \mathrm{C}, \quad \mathrm{N}-\mathrm{TiO}_{2}$ photocatalyst. Table 23, Fig. 20 discusses the degradation using photocatalyst on Basic Fuchsin dye, reveals that the dye has photodegraded from 0.953 to 0.692 in light with $0.03 \mathrm{~g}, 1: 2,600^{\circ} \mathrm{C}, \quad \mathrm{N}-\mathrm{TiO}_{2}$ photocatalyst.

\section{Conclusion}

In this paper, Titanium dioxide has been viewed as a good photocatalyst due to its favorable properties. The experiment was to bring out the achievement of the $\mathrm{TiO}_{2}$ photocatalyst through non metal doping which can be introduced as a substitute in the titanium dioxide lattice; however an effectual assessment is needed to tackle when it comes to solving issues and for material commercializing.

\section{References}

[1] Khezrianjoo and Revanasiddappa, Photodegradation of Acid Yellow 36 using Zinc Oxide photocatalyst in aqueous media, Journal of Catalysts, 582058, 1-6, (2013).

[2] Singh and Srivastava, Mechanism of Dye Degradation during Electrochemical Treatment, The Journal of Physical Chemistry C, 1-32, (2013).

[3] Begum and Gogoi, Photocatalytic degradation of Crystal Violet dye on the surface of $\mathrm{Au}$ doped $\mathrm{TiO}_{2}$ nanoparticles, Indian Journal of Chemical Technology, Vol 24, 97 101, (2017).

[4] Selvaraj and Parimiladevi, Synthesis of Nitrogen Doped Titanium Dioxide $\left(\mathrm{TiO}_{2}\right)$ and its Photocatalytic Performance for the Degradation of Indigo Carmine Dye, Journal of Environmental and Nanotechnology, Vol 2 (Issue 1): 35-41, (2013).

[5] Lydia and Raj, Synthesis and Characterization of Photocatalyst for the Photodegradation Process of Detergent for Potential Applications, International Journal of Advanced Scientific Research and Management, ICAMA18 (Issue 4): 1-6, (2019). 